\title{
Status Kesuburan Tanah Berdasarkan Aspek Kimia dan Fisik Tanah di DAS Wai Ela, Negeri Lima, Kabupaten Maluku Tengah, Provinsi Maluku
}

\author{
Determination of Soil Fertility Status According to Soil Chemical and Physical Aspects Based On \\ Geographic Information System in Wai Ela Watershed, Negeri Lima, Central Maluku, Maluku \\ Province
}

\author{
Hetti May Rini Pintu Batu1, Silwanus M. Talakua ${ }^{2, *}$, Adelina Siregar², Rafael Osok ${ }^{2}$ \\ ${ }^{1}$ Program Studi Agroteknologi, Jurusan Budidaya Pertanian Fakultas Pertanian Universitas Pattimura Jl. Ir. M. \\ Putuhena, Kampus Poka Ambon, 97233 \\ ${ }^{2}$ Program Studi Ilmu Tanah, Jurusan Budidaya Pertanian, Fakultas Pertanian Universitas Pattimura Jl. Ir. M. Putuhena, \\ Kampus Poka Ambon, 97233 \\ *E-mail Penulis Korespondensi: silwanustalakua@yahoo.com
}

\begin{abstract}
Soil fertility problems in Wai Ela Negeri Lima are caused by 1) natural factors such as geology, soil, topography, and land uses; 2) land management system, such as shifting cultivation and deforestation; and (3) land degradation due to a natural disaster such as the fast flood in Wai Ela watershed. The objectives of the study were 1) to study soil chemical and physical characteristics of Wai Ela watershed; 2) to determine the soil fertility status of Wai Ela watershed; and 3) to provide some recommendations to improve the soil fertility. Soil properties used in determining soil fertility status included $\mathrm{CEC}, \mathrm{BS}, \mathrm{C}$-organic, available $\mathrm{P}_{2} \mathrm{O}_{5}, \mathrm{~N}$-total, $\mathrm{pH}$, soil depth, soil textures, and soil permeability rates. The soil fertility status was determined by using PPT's criteria. Data preparation and analysis were conducted by using Geographic Information System. The study results showed that the soil fertility status of Wai Ela watershed ranged from the low-class 217.74ha (14.50\%) to medium class 899.56 ha (60.21\%) and high-class 303.35ha (20.31\%). The recommended soil fertility status improvements in Wai Ela include balanced-fertilization management, increasing soil organic matter by applying manure and compost at soil tillage stage, neutralizing the soil pH and applying irrigation water management.
\end{abstract}

Keywords: chemical and physical aspects, Negeri Lima, soil fertility, Wai Ela Watershed

\begin{abstract}
ABSTRAK
Masalah kesuburan tanah di DAS Wai Ela Negeri Lima disebabkan oleh: 1) faktor alami yaitu geologi, jenis tanah, topografi dan penggunaan lahan; 2) pola pemanfaatan lahan, yaitu perladangan berpindah dan penebangan hutan; dan 3) degradasi lahan akibat bencana alam berupa banjir bandang di danau Wai Ela. Penelitian ini bertujuan untuk: 1) Mengkaji data kimia dan fisika tanah di DAS Wai Ela; 2) Menetapkan status kesuburan tanah di DAS Wai Ela; dan 3) Menentukan arahan perbaikan kesuburan. Sifat kimia tanah yang berpengaruh terhadap penetapan status kesuburan tanah adalah KTK, $\mathrm{KB}$, C-organik, $\mathrm{P}_{2} \mathrm{O}_{5}$ tersedia, $\mathrm{N}$ total dan $\mathrm{pH}$ tanah. Sifat fisika tanah seperti kedalaman tanah, tekstur dan laju permeabilitas tanah. Penentuan status kesuburan tanah ditetapkan berdasarkan kriteria penentuan tingkat kesuburan tanah PPT (1983) dan kriteria kombinasi kesuburan fisika tanah (Sitorus, 1985). Tahap persiapan sampai pengolahan data status kesuburan tanah adalah berbasis SIG. Hasil penelitian menunjukkan bahwa status kesuburan tanah total pada lokasi penelitian yaitu kelas rendah 216,74 ha (14,50\%), kelas sedang 899,56 ha (60,21\%) sampai kelas tinggi 303,35 ha $(20,31 \%)$. Arahan perbaikan kesuburan tanah di DAS Wai Ela adalah manajemen pemupukan berimbang, penambahan bahan organik (pupuk kandang, pupuk hijau) pada tahapan pengolahan tanah, manajemen $\mathrm{pH}$ tanah yang sesuai dan pengaturan air irigasi yang tepat.
\end{abstract}

Kata kunci: aspek kimia dan fisik, DAS Wai Ela, kesuburan tanah, Negeri Lima

\section{PENDAHULUAN}

Tanah merupakan sumber daya alam yang sangat berfungsi penting dalam kelangsungan hidup mahluk hidup. Bukan hanya fungsinya sebagai tempat berjangkarnya tanaman, penyedia sumber daya penting dan tempat berpijak tetapi juga fungsinya sebagai suatu bagian dari ekosistem. Penurunan fungsi tanah tersebut 
dapat menyebabkan terganggunya ekosistem di sekitarnya termasuk juga di dalamnya manusia (Sutanto, 2005 dalam Waluyaningsih, 2008).

Kualitas tanah adalah kapasitas suatu tanah untuk berfungsi dalam batasan ekosistemnya dan berinteraksi positif dengan lingkungan eksternal dari ekosistem tersebut (Larson and Pierce, 1991 dalam Waluyaningsih, 2008). Kualitas tanah mengintegrasikan komponen fisik, kimia dan biologi tanah serta interaksinya. Kualitas tanah menggambarkan kesesuaian sifat-sifat fisik, kimia dan biologi tanah yang secara bersama-sama berfungsi sebagai: 1) media untuk pertumbuhan tanaman dan aktivitas biologi; 2) pengatur dan pembagi aliran air dan penyimpanannya dalam lingkungan; dan 3) penyangga lingkungan dari perusakan oleh senyawa berbahaya, (Jordan and Kremer, 1994).

Kesuburan tanah adalah kemampuan suatu tanah untuk menyediakan unsur hara, pada takaran dan kesetimbangan tertentu secara berkesinambung, untuk menunjang pertumbuhan suatu jenis tanaman pada lingkungan dengan faktor pertumbuhan lainnya dalam keadaan menguntungkan, makin tinggi ketersediaan hara, maka tanah tersebut makin subur dan sebaliknya. Kandungan unsur hara dalam tanah selalu berubah-ubah, tergantung pada musim, pengolahan tanah dan jenis tanaman (Jauhari, 2009). Terjadinya degradasi lahan pada suatu DAS dapat diindikasikan dengan indikator degradasi lahan di lapangan (field assessment). Hal ini sesuai dengan hasil penelitian Talakua dan Osok (2019) yang menyatakan bahwa degradasi lahan yang terjadi di sub DAS Wae Sari dan DAS Wai Rinapa Kecamatan Kairatu diindikasikan dengan adanya pedestal, akar terekspos (erosi lembar), alur dan parit.

Menurut Stocking dan Murnaghan (2000) dalam Talakua (2016), kerusakan tanah dapat terjadi oleh beberapa tipe penyebabnya yaitu: erosi tanah oleh air, erosi tanah oleh angin, kemerosotan kesuburan tanah (yang terdiri dari penurunan kandungan bahan organik tanah, kerusakan struktur tanah, pengurangan aerasi tanah, penurunan kapasitas pengikat air, defisiensi unsur hara, penimbunan senyawa-senyawa yang bersifat toksik bagi tanaman), penggenangan, peningkatan kandungan garam, sedimentasi, penurunan muka air tanah, kehilangan penutupan lahan/vegetasi dan peningkatan batuan pada permukaan lahan. Menurut Arsyad (1989), kerusakan tanah dapat terjadi oleh: 1) kehilangan unsur hara dan bahan organik dari daerah perakaran; 2) terkumpulnya garam di daerah perakaran, terkumpulnya unsur atau senyawa yang merupakan racun bagi tanaman; 3) penjenuhan tanah oleh air; dan 4) erosi.

Daerah Aliran Sungai (DAS) merupakan suatu hamparan wilayah atau kawasan yang dibatasi oleh pembatas topografi (punggung/pinggir bukit) yang berfungsi sebagai satu antang kapan air hujan yang berakhir pada satu muara sungai (Delvian, 2010). Ekosistem DAS, terutama DAS bagian hulu merupakan bagian yang penting karena mempunyai fungsi perlindungan terhadap keseluruhan bagian DAS. DAS Wai Ela di Desa Negeri Lima Kecamatan Leihitu Kabupaten Maluku Tengah merupakan salah satu DAS di Maluku yang mendapat perhatian serius secara nasional. Hal ini, karena selain sangat vital sebagai sumber air bersih untuk berbagai kebutuhan masyarakat dan untuk mendukung pertumbuhan dan produktifitas pertanian, perkebunan, kehutanan, DAS Wai Ela juga merupakan wilayah hunian. Kondisi ini mendorong terjadinya perubahan penggunaan lahan yang cepat, sehingga potensi degradasi lahan akibat erosi cenderung meningkat dari waktu ke waktu yang berpengaruh pada kesuburan tanahnya, dimana pada musim hujan terjadi banjir dan sedimen tinggi dan pada musim kemarau terjadi penurunan debit aliran yang drastis.

Pada tahun 2012, DAS Wai Ela mengalami bencana alam berupa gempa tektonik yang menyebabkan longsoran massa batuan dan tanah dengan skala yang sangat besar menutupi permukaan sungai, sehingga terbentuk Danau Wai Ela. Pada 25 Juli 2013 dengan intensitas curah hujan yang sangat tinggi menyebabkan jebolnya Danau Wai Ela diikuti terjadinya banjir bandang yang sangat besar. Kondisi ini memberi dampak yang besar terhadap tatanan kehidupan masyarakat dan meningkatnya degradasi lahan serta menurunnya kesuburan tanah di DAS Wai Ela Negeri Lima. Hal ini juga menunjukkan bahwa secara alami lokasi penelitian ini rentan terhadap kerusakan tanah. Metode yang digunakan untuk mengetahui informasi sebaran dan tingkat kesuburan tanah adalah metode Sistem Informasi Geografis (SIG) dan Penginderaan Jauh (PJ). Aplikasi SIG dan Penginderaan Jauh diharapkan akan sangat bermanfaat untuk mengetahui dan memetakan penyebaran kelas kesuburan tanah dan memberikan gambaran mengenai kondisi DAS sehingga dapat membantu untuk mengetahui dimana letak lahan yang kritis dan lahan yang subur supaya dapat menentukan tindakan atau arahan yang sesuai untuk perbaikan kesuburan tanah khususnya di DAS Wai Ela.

Mata pencaharian penduduk di lahan kering Sub DAS Wai Ela Negeri Lima yang mayoritas sebagai petani, menjadikan semakin pentingnya keberadaan lahan bagi petani. Supaya lahan kering di Sub DAS Wae Ela Negeri Lima tetap dapat berperan sebagai lahan pertanian secara lestari, yaitu mampu untuk mendukung pertumbuhan tanaman secara terus menerus terutama dari aspek kesuburan kimia dan fisik. Maka peneliti tertarik melakukan penelitian mengenai "Penetapan Status Kesuburan Tanah Berdasarkan Aspek Kimia dan Fisik Tanah Berbasis SIG di Das Wai Ela Negeri Lima Kabupaten Maluku Tengah Provinsi Maluku" tersebut. Tujuan yang ingin dicapai dalam penelitian ini adalah: Mengkaji data kimia dan fisika tanah di DAS Wai Ela Negeri Lima, Menetapkan status kesuburan tanah di DAS Wai Ela Negri Lima dan Menentukan arahan perbaikan kesuburan tanahnya.

\section{METODOLOGI PENELITIAN}

Alat dan bahan penelitian yang digunakan adalah GPS (Global Position System) untuk pengukuran koordinat, altimeter untuk pengukuran elevasi, abney level untuk pengukuran kemiringan lereng, kompas 
untuk penentuan azimut/arah, buku Munsell, meter rol $(30 \mathrm{~m})$, meter kecil untuk profil dan boring tanah $(3 \mathrm{~m})$, lup, pH meter, Auger, pacul, sekop, parang, pisau kater, ring sampel, tongkat pengukur, papan kecil, martil, alat tulis menulis, alat hitung (kalkulator), kamera, senter dan set komputer (software Microsoft Office 2010, SPSS 17, Minitab 16 dan ArcGIS 10.1), peta kerja lapangan DAS Wai Ela dengan skala 1:17.500, kartu deskripsi profil, $\mathrm{H}_{2} \mathrm{O}_{2} 30 \%$, $\mathrm{HCl} 10 \%$, Aquades dan ditambah dengan surat-surat, perlengkapan penelitian.

Penelitian ini dilaksanakan di Daerah Aliran Sungai (DAS) Wai Ela Negeri Lima Kabupaten Maluku Tengah Provinsi Maluku yang berlangsung dari November 2017 sampai Juli 2018. Penelitian ini menggunakan metode survei berbasis unit lahan sebagai peta kerja lapangan yang didesain berdasarkan hasil tumpang susun (overlay) 4 komponen utama yaitu: kelas topografi, formasi geologi, komponen tanah dan pola penggunaan lahan di DAS Wai Ela Negeri Lima.

Total unit lahan di lokasi penelitian adalah 72 unit.

1. Komponen kelas topografi terdiri atas 7 kelas yaitu "L0" (0-3\%) datar, "L1" (3-8\%) landai, "L2" (8$15 \%)$ agak miring, "L3" (15-30\%) miring, "L4" (30$45 \%$ ) agak curam, "L5" (45-65\%) curam dan "L6" $(<65 \%)$ sangat curam.

2. Komponen formasi geologi terdiri atas 2 formasi yaitu kode "a" untuk formasi geologi Tpav (batuan gunung api Ambon) dengan material penyusun lava breksi gunung api, breksi tuf dan tuf, kode "b" untuk formasi Ti (granit Manipa) dengan material penyusun umumnya terdiri dari granit biotit. Di pulau Manipa batuan ini menerobos satuan filit (batuan malihan tehotu) dengan menunjukkan gejala sentuhan.

Komponen tanah terdiri atas 4 macam tanah, yaitu kode "1" untuk typic humaquepts, kode "2 untuk typic udipsamments, kode " 3 " untuk typic dystrudepts, dan kode " 4 " untuk typic eutrudepts.

3. Komponen pola penggunaan lahan terdiri dari 4 komponen yaitu kode "A" untuk pemukiman, kode "B" untuk pertanian lahan kering, kode "C" untuk hutan lahan kering sekunder dan kode " $\mathrm{D}$ " untuk tanah kosong.
Pengumpulan data lapangan dilakukan pada sampel area yang mewakili semua unit lahan mengikuti jalur-jalur pengamatan yang telah ditetapkan pada setiap sampel area. Jumlah sampel area yang digunakan untuk pengamatan adalah 15 unit. Tipe observasi pada sampel area adalah survey bebas dengan jarak observasi profil dan boring.

\section{Analisis data}

\section{Penilaian sifat kimia tanah}

Proses analisis status kesuburan tanah diawali dengan penilaian sifat kimia tanah berdasarkan kriteria Pusat Penelitian Tanah, Bogor (1983). Terdapat lima parameter tanah yang digunakan dalam penelitian ini untuk menilai status kesuburan tanah yaitu Kapasitas Tukar Kation, Kejenuhan Basa, C-organik, kadar $\mathrm{P}_{2} \mathrm{O}_{5}$ tersedia, $\mathrm{N}$ total tanah dan $\mathrm{pH}$ tanah. Kadar unsur hara tanah yang diperoleh dari analisis tanah bila dibandingkan dengan kebutuhan unsur hara masingmasing tanaman, maka dapat diketahui apakah status unsur hara dalam tanah tersebut sangat rendah, rendah, sedang, tinggi dan sangat tinggi sesuai kriteria yang sudah ditetapkan seperti pada Tabel 1 .

\section{Penilaian Sifat Fisika Tanah}

Proses analisis status kesuburan tanah setelah penilaian sifat kimia tanah adalah penilaian sifat fisika tanah berdasarakan kriteria penilaian sifat fisika tanah (Sitorus, 1985). Terdapat tiga parameter tanah yang digunakan dalam menilai sifat fisik tanah yaitu kedalaman tanah, tekstur tanah dan laju permeabilitas. Berdasarkan kriteria yang sudah ditetapkan maka akan dihasilkan status penilaian sifat fisiknya yaitu rendah, sedang dan tinggi seperti yang sudah tertera didalam Tabel 2.

\section{Penentuan Tingkat Kesuburan Tanah dari Aspek Kimia Tanah}

Setelah sifat kimianya ditentukan selanjutnya ditentukan status kesuburan tanah setiap unit lahan berdasarkan PPT (1983) kemudian dipadukan dengan karakteristik sifat fisik tanah untuk mengkaji status kesuburan tanahnya (Tabel 3).

Tabel 1 Kriteria penilaian sifat kimia tanah (Pusat Penelitian Tanah, 1983)

\begin{tabular}{ccccccc}
\hline Sifat Tanah & Sangat rendah & Rendah & Sedang & Tinggi & Sangat tinggi & Ket \\
\hline $\mathrm{C}(\%)$ & $<1,00$ & $1,00-2,00$ & $2,01-3,00$ & $3,01-5,00$ & $>5,00$ \\
$\mathrm{~N}(\%)$ & $<0,10$ & $0,10-0.20$ & $0,21-0,50$ & $0,51-0,75$ & $>0,75$ \\
$\mathrm{P}_{2} \mathrm{O}_{5}$ Olsen $(\mathrm{ppm})$ & $<10$ & $10-25$ & $26-45$ & $46-60$ & $>60$ \\
$\mathrm{KTK}(\mathrm{me} / 100 \mathrm{~g})$ & $<5$ & $5-16$ & $17-24$ & $25-40$ & $>40$ & \\
$\mathrm{~KB}(\%)$ & $<20$ & $20-35$ & $36-50$ & $51-70$ & $>70$ & \\
\hline $\mathrm{pH} \mathrm{H} 2 \mathrm{O}$ & Sangat Masam & Masam & Agak Masam & Netral & Agak Alkalis & Alkalis \\
\cline { 2 - 7 } & $<4,5$ & $4,5-5,5$ & $5,6-6,5$ & $6,6-7,5$ & $7,6-8,5$ & $>8,5$ \\
\hline
\end{tabular}


Tabel 2. Kriteria penilaian sifat fisik tanah (Sitorus, 1985)

\begin{tabular}{|c|c|c|c|}
\hline $\begin{array}{c}\text { Kedalaman } \\
\text { efektif tanah }(\mathrm{cm})\end{array}$ & Tekstur tanah & Permeabilitas tanah $(\mathrm{cm} / \mathrm{jam})$ & Kelas \\
\hline$<25$ & $\begin{array}{l}\text { Pasir, Liat berdebu, } \\
\text { Liat }\end{array}$ & $\begin{array}{l}\text { Lambat-sangatlambat/cepat- } \\
\text { sangat cepat, cepat }(0,5-\end{array}$ & Rendah \\
\hline $25-50$ & $\begin{array}{l}\text { Liat berpasir, Pasir berlempung, } \\
\text { Lempung berliat, Debu }\end{array}$ & $\begin{array}{l}>12.5) \\
\text { Agak lambat atrau agak } \\
\text { cepat }(0,5-2 \text { atau } 6,25-12,5)\end{array}$ & Sedang \\
\hline$>50$ & Lempung, Lempung berpasir & Sedang $(2-6,5)$ & Tinggi \\
\hline
\end{tabular}

Tabel 3. Kriteria penentuan tingkat/status kesuburan tanah PPT (1983)

\begin{tabular}{|c|c|c|c|c|}
\hline No & KTK & KB & $\mathrm{C}$-Org, $\mathrm{P}_{2} \mathrm{O}_{5}, \mathrm{~N}$-total & Status/tingkat \\
\hline 1 & $\mathrm{~T}$ & $\mathrm{~T}$ & $\geq 2 \mathrm{~T}$ tanpa $\mathrm{R}$ & $\mathrm{T}$ \\
\hline 2 & $\mathrm{~T}$ & $\mathrm{~T}$ & $\geq 2 \mathrm{~T}$ dengan $\mathrm{R}$ & $S$ \\
\hline 3 & $\mathrm{~T}$ & $\mathrm{~T}$ & $\geq 2 \mathrm{~S}$ tanpa $\mathrm{R}$ & $\mathrm{T}$ \\
\hline 4 & $\mathrm{~T}$ & $\mathrm{~T}$ & $\geq 2 \mathrm{~S}$ dengan $\mathrm{R}$ & $S$ \\
\hline 5 & $\mathrm{~T}$ & $\mathrm{~T}$ & TSR & $S$ \\
\hline 6 & $\mathrm{~T}$ & $\mathrm{~T}$ & $\leq 2 \mathrm{~S}$ tanpa $\mathrm{R}$ & S \\
\hline 7 & $\mathrm{~T}$ & $\mathrm{~T}$ & $\leq 2 \mathrm{~S}$ dengan $\mathrm{R}$ & $\mathrm{R}$ \\
\hline 8 & $\mathrm{~T}$ & S & $\geq 2 \mathrm{~T}$ tanpa $\mathrm{R}$ & $\mathrm{T}$ \\
\hline 9 & $\mathrm{~T}$ & $S$ & $\geq 2 \mathrm{~T}$ dengan $\mathrm{R}$ & $S$ \\
\hline 10 & $\mathrm{~T}$ & S & $\geq 2 \mathrm{~S}$ & $S$ \\
\hline 11 & $\mathrm{~T}$ & $\mathrm{~S}$ & Kombinasi yang lain & $\mathrm{R}$ \\
\hline 12 & $\mathrm{~T}$ & $\mathrm{R}$ & $\geq 2 \mathrm{~T}$ tanpa $\mathrm{R}$ & $S$ \\
\hline 13 & $\mathrm{~T}$ & $\mathrm{R}$ & $\geq 2 \mathrm{~T}$ dengan $\mathrm{R}$ & $\mathrm{R}$ \\
\hline 14 & $\mathrm{~T}$ & $\mathrm{R}$ & Kombinasi yang lain & $\mathrm{R}$ \\
\hline 15 & $S$ & $\mathrm{~T}$ & $\geq 2 \mathrm{~T}$ tanpa $\mathrm{R}$ & $S$ \\
\hline 16 & S & $\mathrm{T}$ & $\geq 2 \mathrm{~S}$ tanpa $\mathrm{R}$ & $S$ \\
\hline 17 & $S$ & $\mathrm{~T}$ & Kombinasi yang lain & $\mathrm{R}$ \\
\hline 18 & $S$ & $S$ & $\geq 2 \mathrm{~T}$ tanpa $\mathrm{R}$ & $S$ \\
\hline 19 & S & S & $\geq 2 \mathrm{~S}$ tanpa $\mathrm{R}$ & $S$ \\
\hline 20 & $S$ & $\mathrm{~S}$ & Kombinasi yang lain & $\mathrm{R}$ \\
\hline 21 & $S$ & $\mathrm{R}$ & $3 \mathrm{~T}$ & $S$ \\
\hline 22 & S & $\mathrm{R}$ & Kombinasi yang lain & $\mathrm{R}$ \\
\hline 23 & $\mathrm{R}$ & $\mathrm{T}$ & $\geq 2 \mathrm{~T}$ tanpa $\mathrm{R}$ & $S$ \\
\hline 24 & $\mathrm{R}$ & $\mathrm{T}$ & $\geq 2 \mathrm{~T}$ dengan $\mathrm{R}$ & $\mathrm{R}$ \\
\hline 25 & $\mathrm{R}$ & $\mathrm{T}$ & $\geq 2 \mathrm{~S}$ tanpa $\mathrm{R}$ & $S$ \\
\hline 26 & $\mathrm{R}$ & $\mathrm{T}$ & Kombinasi yang lain & $\mathrm{R}$ \\
\hline 27 & $\mathrm{R}$ & $\mathrm{S}$ & $\geq 2 \mathrm{~T}$ tanpa $\mathrm{R}$ & $\mathrm{R}$ \\
\hline 28 & $\mathrm{R}$ & $S$ & Kombinasi yang lain & $\mathrm{R}$ \\
\hline 29 & $\mathrm{R}$ & $\mathrm{R}$ & Semua kombinasi & $\mathrm{R}$ \\
\hline 30 & SR & $\mathrm{T} / \mathrm{R} / \mathrm{S}$ & Semua kombinasi & SR \\
\hline
\end{tabular}

Keterangan: $\mathrm{T}=$ Tinggi; $\mathrm{S}=$ Sedang; $\mathrm{R}=$ Rendah

\section{Penentuan Status Kesuburan Tanah dari Aspek Fisika Tanah}

Setelah penentuan status kesuburan tanah dari aspek kima tanah selanjutnya penentuan status kesuburan tanah dari aspek fisika tanah berdasarakan kombinasi kesuburan fisika tanah (Sitorus, 1985).

\section{Penetapan Status Kesuburan Total}

Penetapan status kesuburan tanah total dihasilkan setelah penetapan status kesuburan dari aspek kimia tanah dan penentapan status kesuburan dari aspek fisika tanah sudah ditetapkan, seperti yang tertera pada Tabel 5 .

\section{Menentukan Arahan Perbaikan Kesuburan Tanah}

Arahan perbaikan kesuburan tanah dibuat berdasarkan status kesuburan tanahnya dengan memperhatikan sifat kimia dan fisik tanah mana yang berada dalam kondisi kesuburan yang paling rendah/kritis (minimum).

Secara kimia arahan perbaikan kesuburan tanah beriorentasi kepada pemberian pupuk dan pemberian bahan organik (kompos). Secara fisik berorientasi kepada perbaikan secara mekanis melalui pengelolaan tanah dan pemberian bahan organik (kompos) serta penanaman tanaman legum (vegetasi yang sesuai). 
Tabel 4. Kombinasi kesuburan fisika tanah (Sitorus, 1985)

\begin{tabular}{|c|c|c|c|c|}
\hline No & $\begin{array}{l}\text { Kedalaman efektif } \\
\text { Tanah }\end{array}$ & Tekstur tanah & $\begin{array}{c}\text { Permeabilitas } \\
\text { Tanah }\end{array}$ & $\begin{array}{l}\text { Kesuburan } \\
\text { Fisika }\end{array}$ \\
\hline 1 & $\mathrm{~T}$ & $\mathrm{~T}$ & $\mathrm{~T}$ & $\mathrm{~T}$ \\
\hline 2 & $\mathrm{~T}$ & $\mathrm{~T}$ & S & $\mathrm{T}$ \\
\hline 3 & $\mathrm{~T}$ & $\mathrm{~T}$ & $\mathrm{R}$ & S \\
\hline 4 & $\mathrm{~T}$ & $\mathrm{~S}$ & $\mathrm{~T}$ & $\mathrm{~T}$ \\
\hline 5 & $\mathrm{~T}$ & $S$ & S & S \\
\hline 6 & $\mathrm{~T}$ & $\mathrm{~S}$ & $\mathrm{R}$ & S \\
\hline 7 & $\mathrm{~T}$ & $\mathrm{R}$ & $\mathrm{T}$ & $S$ \\
\hline 8 & $\mathrm{~T}$ & $\mathrm{R}$ & S & $S$ \\
\hline 9 & $\mathrm{~T}$ & $\mathrm{R}$ & $\mathrm{R}$ & $\mathrm{R}$ \\
\hline 10 & S & $\mathrm{T}$ & $\mathrm{T}$ & $\mathrm{T}$ \\
\hline 11 & S & $\mathrm{T}$ & S & S \\
\hline 12 & S & $\mathrm{T}$ & $\mathrm{R}$ & S \\
\hline 13 & S & $\mathrm{S}$ & $\mathrm{T}$ & S \\
\hline 14 & S & $\mathrm{S}$ & S & S \\
\hline 15 & S & $\mathrm{S}$ & $\mathrm{R}$ & S \\
\hline 16 & $S$ & $\mathrm{R}$ & $\mathrm{T}$ & $S$ \\
\hline 17 & $S$ & $\mathrm{R}$ & $S$ & $\mathrm{~S}$ \\
\hline 18 & S & $\mathrm{R}$ & $\mathrm{R}$ & $\mathrm{R}$ \\
\hline 19 & $\mathrm{R}$ & $\mathrm{T}$ & $\mathrm{T}$ & S \\
\hline 20 & $\mathrm{R}$ & $\mathrm{T}$ & S & S \\
\hline 21 & $\mathrm{R}$ & $\mathrm{T}$ & $\mathrm{R}$ & $\mathrm{R}$ \\
\hline 22 & $\mathrm{R}$ & $\mathrm{S}$ & $\mathrm{T}$ & $\mathrm{S}$ \\
\hline 23 & $\mathrm{R}$ & $\mathrm{S}$ & S & $S$ \\
\hline 24 & $\mathrm{R}$ & $\mathrm{S}$ & $\mathrm{R}$ & $\mathrm{R}$ \\
\hline 25 & $\mathrm{R}$ & $\mathrm{R}$ & $\mathrm{T}$ & $\mathrm{R}$ \\
\hline 26 & $\mathrm{R}$ & $\mathrm{R}$ & $S$ & $\mathrm{R}$ \\
\hline 27 & $\mathrm{R}$ & $\mathrm{R}$ & $\mathrm{R}$ & $\mathrm{R}$ \\
\hline
\end{tabular}

Keterangan: $\mathrm{T}=$ Tinggi; $\mathrm{S}=$ Sedang; $\mathrm{R}=$ Rendah

Tabel 5. Penetapan kesuburan tanah total (PPT, 1983)

\begin{tabular}{ccc}
\hline $\begin{array}{c}\text { Kesuburan } \\
\text { kimia tanah }\end{array}$ & $\begin{array}{c}\text { Kesuburan fisik } \\
\text { tanah }\end{array}$ & $\begin{array}{c}\text { Kesuburan } \\
\text { tanah total }\end{array}$ \\
\hline $\mathrm{T}$ & $\mathrm{T}$ & $\mathrm{T}$ \\
$\mathrm{S}$ & $\mathrm{T}$ & $\mathrm{T}$ \\
$\mathrm{R}$ & $\mathrm{T}$ & $\mathrm{S}$ \\
$\mathrm{T}$ & $\mathrm{S}$ & $\mathrm{T}$ \\
$\mathrm{S}$ & $\mathrm{S}$ & $\mathrm{S}$ \\
$\mathrm{R}$ & $\mathrm{S}$ & $\mathrm{R}$ \\
$\mathrm{T}$ & $\mathrm{R}$ & $\mathrm{S}$ \\
$\mathrm{S}$ & $\mathrm{R}$ & $\mathrm{R}$ \\
$\mathrm{R}$ & $\mathrm{R}$ & $\mathrm{R}$ \\
\hline
\end{tabular}

Keterangan: $\mathrm{T}=$ Tinggi; $\mathrm{S}=$ Sedang; $\mathrm{R}=$ Rendah

\section{HASIL DAN PEMBAHASAN}

\section{Hasil Analisis Sifat Kimia Tanah di DAS Wai Ela}

Hasil analisis kimia tanah di DAS Wai Ela Negeri Lima Kabupaten Maluku Tengah Provinsi Maluku disajikan pada Tabel 6. Hasil penelitian menunjukkan bahwa status kesuburan tanah berdasarkan aspek kimia tanah dapat ditetapkan berdasarkan Kriteria Penentuan
Status Kesuburan Tanah PPT (1983) dengan parameter $\mathrm{KTK}, \mathrm{KB}, \mathrm{C}$-org, $\mathrm{P}_{2} \mathrm{O}_{5}$ tersedia dan $\mathrm{N}_{\text {tot. }}$. Hasil dari penetapan status kesuburan berdasarkan aspek kimia tersebut berkisar antara rendah $(\mathrm{R})$ dengan luas lahan 13,96 $\mathrm{Ha}$ atau 0,93\% pada tanah Aluvial Eutrik dan sedang (S) terdapat pada tanah Kambisol Distrik, Kambisol Eutrik, Gleisol Eutrik, Litosol dan Molisol Haplik dengan luas lahan 1405,70 Ha atau 94,10 $\%$.Perbedaan status kesuburan tersebut dikarenakan adanya faktor pembatas pada masing-masing jenis tanah. Pada tanah Aluvial Eutrik memiliki faktor pembatas yaitu C-org (S), $\mathrm{P}_{2} \mathrm{O}_{5}(\mathrm{R})$ dan $\mathrm{N}_{\text {tot }}(\mathrm{SR})$, Tanah Gleisol memiliki faktor pembatas yaitu $\mathrm{N}_{\text {tot }}(\mathrm{R})$, tanah Kambisol Eutrik memiliki faktor pembatas yaitu C_org (SR) dan $\mathrm{N}_{\text {tot }}(\mathrm{R})$, sedangkan pada tanah Kambiso Distrik memiliki faktor pembatas yaitu $\mathrm{N}_{\text {tot }}(\mathrm{R})$, pada tanah Molisol Haplik memiliki faktor pembatas yaitu $\mathrm{N}_{\text {tot }}(\mathrm{SR})$ dan pada tanah Litosol memiliki faktor pembatas yaitu $\mathrm{P}_{2} \mathrm{O}_{5} \quad(\mathrm{R})$ dan $\mathrm{N}_{\text {tot }}$ (SR). Faktor-Faktor Pembatas tersebutlah yang mengakibatkan perbedaan tingkat status kesuburan pada aspek kimia di lokasi penelitian. Peta kesuburan kimia tanah disajikan pada Gambar 1. 
Tabel 6. Status kesuburan tanah berdasarkan aspek kimia tanah

\begin{tabular}{|c|c|c|c|c|c|c|c|}
\hline \multirow{2}{*}{$\begin{array}{c}\text { Status } \\
\text { Kesuburan } \\
\end{array}$} & \multirow{2}{*}{ Jenis Tanah } & \multirow{2}{*}{ Unit Lahan } & \multirow{2}{*}{ Parameter } & \multirow{2}{*}{ Nilai } & \multirow{2}{*}{ Kelas } & \multicolumn{2}{|c|}{ Luas } \\
\hline & & & & & & $\mathrm{Ha}$ & $\%$ \\
\hline \multirow[t]{5}{*}{ Rendah } & Aluvial & L0a1A, L0a1D, & KTK (me/100 g) & 38,39 & $\mathrm{~T}$ & 13,96 & 0,93 \\
\hline & Eutrik & L0a1K, L1a1A, & $\mathrm{KB}(\%)$ & 100 & ST & & \\
\hline & & L1a1B, L1a1D, & C_Organik (\%) & 2,03 & $\mathrm{~S}$ & & \\
\hline & & L1a1K & $\mathrm{P}_{2} \mathrm{O}_{5}(\mathrm{ppm})$ & 24 & $\mathrm{R}$ & & \\
\hline & & & $\mathrm{N}(\%)$ & 0,08 & SR & & \\
\hline \multirow[t]{26}{*}{ Sedang } & Gleisol & L0a2C & KTK (me/100 g) & 50,27 & ST & 2,15 & 0,14 \\
\hline & & & $\mathrm{KB}(\%)$ & 80 & ST & & \\
\hline & & & C_Organik (\%) & 4,76 & $\mathrm{~T}$ & & \\
\hline & & & $\mathrm{P}_{2} \mathrm{O}_{5}(\mathrm{ppm})$ & 59 & $\mathrm{~T}$ & & \\
\hline & & & $\mathrm{N}(\%)$ & 0,1 & $\mathrm{R}$ & & \\
\hline & Kambisol & $\begin{array}{c}\text { L0a3A, L0a3D, L0a3E, L0a3F, } \\
\text { L1a3J, L2a3A, L2a3E, L1a3G, L1a3H, } \\
\text { L1a3I, L1a3E, L0a3J }\end{array}$ & KTK (me/100 g) & 29,81 & $\mathrm{~T}$ & 303,35 & 20,31 \\
\hline & Eutrik & L2a3G, L2a3H, L2a3I, L0a3I & $\mathrm{KB}(\%)$ & 100 & ST & & \\
\hline & & L2a3J, L3a3E, L3a3G, L0a3H & C_Organik (\%) & 0,5 & SR & & \\
\hline & & L3a3H, L3a3I, L3a3J, L0a3G & $\mathrm{P}_{2} \mathrm{O}_{5}(\mathrm{ppm})$ & 90 & ST & & \\
\hline & & L4a3G, L4a3H, L4a3J & $\mathrm{N}(\%)$ & 0,1 & $\mathrm{R}$ & & \\
\hline & & L0a4G, L0a4I, L0a4J, L0b4G, & & & & 876,66 & 58,68 \\
\hline & Kambisol & L1a4E, L1a4G, L1a4I, L1a4J, & KTK (me/100 g) & 52,38 & ST & & \\
\hline & Distrik & L1b4G, L2a4E, L2a4G, L2a4I & $\mathrm{KB}(\%)$ & 84 & ST & & \\
\hline & & L2a4J, L2b4G, L3a4E, L3a4G & C_Organik (\%) & 5,44 & ST & & \\
\hline & & L3a4I, L3a4J, L3b4G, L4a4G, & $\mathrm{P}_{2} \mathrm{O}_{5}(\mathrm{ppm})$ & 66 & ST & & \\
\hline & & L4a $4 \mathrm{~J}$ & $\mathrm{~N}(\%)$ & 0,1 & $\mathrm{R}$ & & \\
\hline & Molisol & L2a5A, & KTK (me/100 g) & 34,71 & $\mathrm{~T}$ & 8,94 & 0,60 \\
\hline & Haplik & L2a5D, & $\mathrm{KB}(\%)$ & 98 & ST & & \\
\hline & & L3a5D & C_Organik (\%) & 4,4 & $\mathrm{~T}$ & & \\
\hline & & & $\mathrm{P}_{2} \mathrm{O}_{5}(\mathrm{ppm})$ & 99 & ST & & \\
\hline & & & $\mathrm{N}(\%)$ & 0,09 & SR & & \\
\hline & & L4a6E, L4a6G, L5a6G, L5a6J, & KTK (me/100 g) & 27,94 & $\mathrm{~T}$ & 214,59 & 14,36 \\
\hline & Litosol & L6a6G, L6a6H, L6a6J & $\mathrm{KB}(\%)$ & 94 & ST & & \\
\hline & & & C_Organik (\%) & 3,53 & $\mathrm{~T}$ & & \\
\hline & & & $\mathrm{P}_{2} \mathrm{O}_{5}(\mathrm{ppm})$ & 18 & $\mathrm{R}$ & & \\
\hline & & & $\mathrm{N}(\%)$ & 0,08 & SR & & \\
\hline \multirow[t]{2}{*}{ Tinggi } & - & - & - & - & - & - & - \\
\hline & Total & & & & & 1419,66 & 95,03 \\
\hline
\end{tabular}

Sumber: Analisis Tanah November 2017- Juli 2018

\section{Hasil Analisis Sifat Fisika Tanah di DAS Wai Ela}

Hasil analisis fisika tanah di DAS Wai Ela Negeri Lima Kabupaten Maluku Tengah Provinsi Maluku disajikan pada Tabel 7. Berdasarkan Tabel 7, status kesuburan tanah berdasarkan aspek fisik tanah ditetapkan berdasarkan Kriteria Kesuburan Fisik Tanah dengan parameter ukuran yaitu kedalaman tanah, tekstur tanah dan laju permeabilitas tanah (Sitorus, 1985). Hasil penetapan status kesuburan berdasarkan apek fisik tanah berkisar antara rendah (R) dengan luas lahan 216,74 Ha atau $14,51 \%$ pada tanah Gleisol Eutrik dan Litosol, sedang (S) dengan luas lahan 885,61 Ha atau 59,28\% pada tanah Kambisol Distrik dan Molisol Haplik dan tinggi (T) dengan luas lahan 317,31 Ha atau 21,24\% pada tanah Kambisol Eutrik dan Aluvial Eutrik.

Perbedaan status kesuburan tersebut dikarenakan adanya faktor pembatas pada masing-masing jenis tanah. Pada tanah Aluvial Eutrik memiliki faktor pembatas yaitu Laju permeabilitas (S), pada tanah Gleisol memiliki faktor pembatas yaitu tekstur (R) dan permeabilitas (R), Kambisol Distrik memiliki faktor pembatas yaitu tekstur (S) dan permeabilitas (R), Molisol Haplik memiliki faktor pembatas yaitu permeabilitas (R) dan pada tanah Litosol memiliki faktor pembatas yaitu kedalaman tanah (R) dan permeabilitas (R). Faktor-Faktor pembatas tersebut mengakibatkan perbedaan tingkat status kesuburan pada aspek fisik di lokasi penelitian. Peta kesuburan fisika tanah disajikan pada Gambar 2.

\section{Penetapan Status Kesuburan Tanah Total}

Penetapan status kesuburan tanah total di DAS Wai Ela Negeri Lima Kabupaten Maluku Tengah Provinsi Maluku dilihat pada Tabel 8. Status kesuburan tanah total didapat dari kombinasi kesuburan fisik tanah dan tingkat kesuburan kimia tanah. Adapun masing-masing status kesuburan tanah total dapat dilihat pada Tabel 8 dan peta sebaran kesuburan tanah dapat dilihat pada Gambar 3.

Status kesuburan tanah total pada lokasi penelitian berkisar antara rendah (R) dengan luasan 216,74 Ha atau 14,51\% pada tanah Gleisol Eutrik dan Litosol dengan kombinasi kesuburan fisika rendah (R) dan kesuburan kimia sedang (S), kesuburan tanah total sedang (S) dengan luasan $899,57 \mathrm{Ha}$ atau $60,22 \%$ pada tanah Kambisol Distrik dan Molisol Haplik dengan kombinasi kesuburan fisika sedang (S) dan kesuburan kimia sedang (S) serta Aluvial Eutrik dengan kombinasi kesuburan fisika tinggi $(\mathrm{T})$ dan kesuburan kimia rendah (R) serta kesuburan tanah total tinggi (T) dengan luas lahan 303,35 Ha atau 20,31\% pada tanah Kambisol Eutrik dengan kombinasi kesuburan fisika tinggi (T) dan kesuburan kimia sedang (S). 
Tabel 7. Status kesuburan tanah berdasarkan aspek fisika

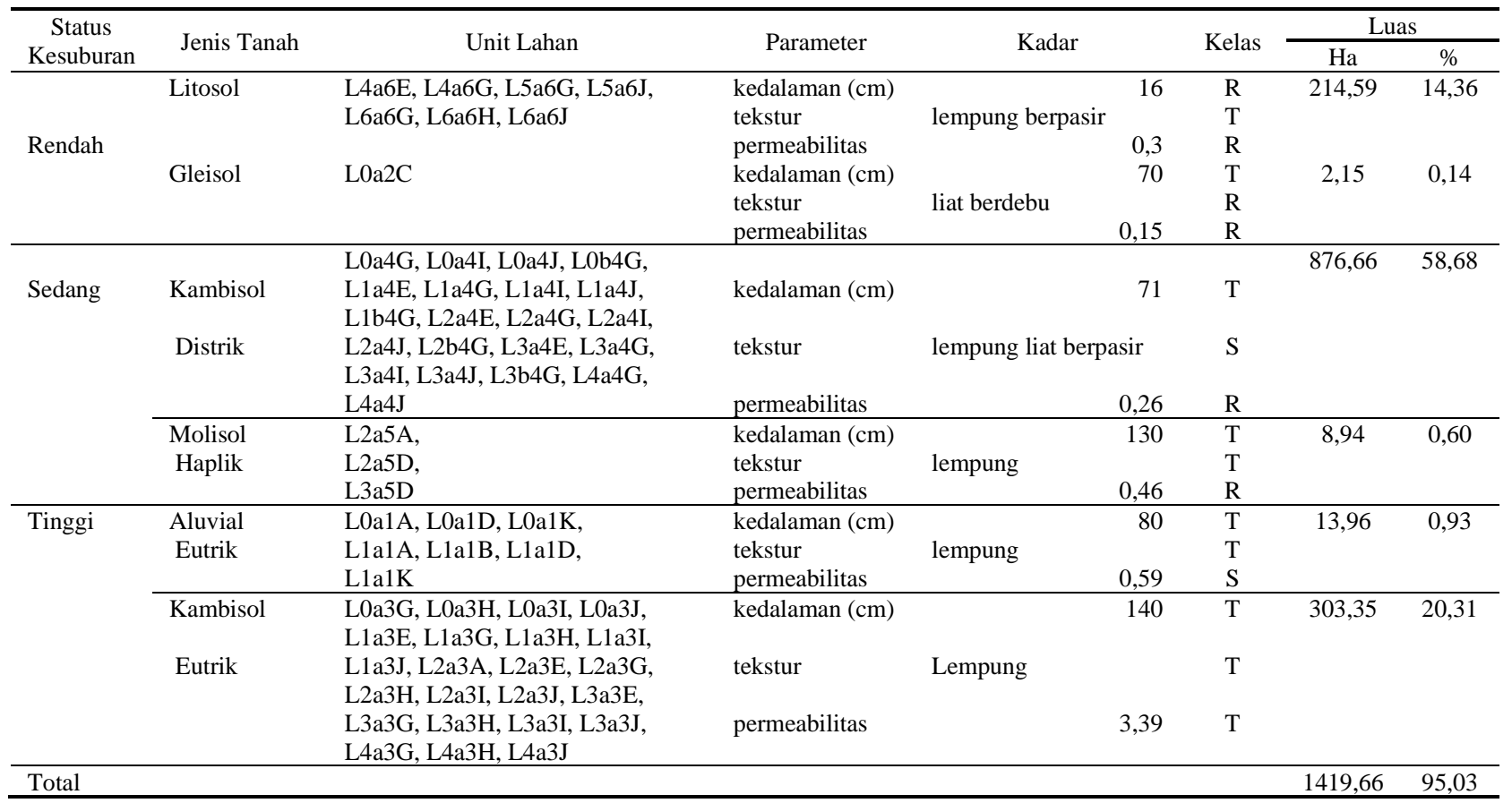

Sumber: Analisis Tanah November 2017- Juli 2018

Tabel 8. Penetapan Status Kesuburan Tanah Total

\begin{tabular}{|c|c|c|c|c|c|c|}
\hline \multirow{2}{*}{$\begin{array}{c}\text { Status } \\
\text { kesuburan }\end{array}$} & \multirow{2}{*}{ Jenis Tanah } & \multirow{2}{*}{ Unit Lahan } & \multicolumn{2}{|c|}{ Kombinasi kesuburan } & \multicolumn{2}{|c|}{ Luas } \\
\hline & & & Fisika & Kimia & $\mathrm{Ha}$ & $\%$ \\
\hline \multirow[t]{3}{*}{ Rendah } & Gleisol Eutrik & L0a2C & $\mathrm{R}$ & $\mathrm{S}$ & 2,15 & 0,14 \\
\hline & Litosol & $\begin{array}{c}\text { L4a6E, L4a6G, L5a6G, L5a6J, L6a6G, L6a6H, } \\
\text { L6a6J }\end{array}$ & $\mathrm{R}$ & S & 214,59 & 14,36 \\
\hline & Aluvial Eutrik & $\begin{array}{l}\text { L0a1A, L0a1D, L0a1K, L1a1A, L1a1B, L1a1D, } \\
\text { L1a1K }\end{array}$ & $\mathrm{T}$ & $\mathrm{R}$ & 13,96 & 0,93 \\
\hline \multirow[t]{2}{*}{ Sedang } & Kambisol Distrik & $\begin{array}{c}\text { L0a4G, L0a4I, L0a4J, L0b4G, L1a4E, L1a4G, } \\
\text { L1a4I, L1a4J, L1b4G, L2a4E, L2a4G, L2a4I, } \\
\text { L2a4J, L2b4G, L3a4E, L3a4G, L3a4I, L3a4J, } \\
\text { L3b4G, L4a4G, L4a4J }\end{array}$ & $S$ & S & 876,66 & 58,68 \\
\hline & Molisol Haplik & L2a5A, L2a5D, L3a5D & $S$ & $S$ & 8,94 & 0,60 \\
\hline Tinggi & Kambisol Eutrik & $\begin{array}{c}\text { L0a3A, L0a3D, L0a3E, L0a3F, L0a3G, L0a3H, } \\
\text { L0a3I, L0a3J, L1a3E, L1a3G, L1a3H, L1a3I, } \\
\text { L1a3J, L2a3A, L2a3E, L2a3G, L2a3H, L2a3I, } \\
\text { L2a3J, L3a3E, L3a3G, L3a3H, L3a3I, L3a3J, } \\
\text { L4a3G, L4a3H, L4a3J }\end{array}$ & $\mathrm{T}$ & $\mathrm{S}$ & 303,35 & 20,31 \\
\hline & Total & & & & 1419,66 & 95,03 \\
\hline
\end{tabular}

Sumber: Analisis Tanah November 2017- Juli 2018

\section{Arahan Perbaikan Kesuburan Tanah}

Berdasarkan data penetapan status kesuburan tanah total yang dihasilkan maka diperoleh tiga status kesuburan tanah, yaitu rendah, sedang dan tinggi. Perbedaan status kesuburan tanah pada lokasi penelitian disebabkan karena adanya faktor pembatas, yaitu seperti yang sudah dijelaskan sebelumnya pada penetapan status kesuburan pada aspek kimia dan fisik.

Usaha perbaikan kesuburan tanah yang dapat dilakukan di lokasi penelitian antara lain manajemen pemupukan berimbang sesuai kebutuhan tanaman, penambahan bahan organik (pupuk kandang, pupuk hijau atau penanaman legume) pada tahapan pengolahan tanah, manajemen $\mathrm{pH}$ tanah yang sesuai untuk ketersediaan unsur dengan pengapuran (menaikkan $\mathrm{pH}$ ), dan pengaturan air irigasi yang tepat. Hal ini didukung oleh hasil penelitian Talakua dan Kaya (2019) yang menyatakan bahwa pemberian bahan organik dapat memperbaiki sifat fisik tanah yaitu menambah berat jenis dan bobot isi, pori drainase cepat, mengakibatkan kapasitas lapang, pori air tersedia dari hasil tanaman jagung. 


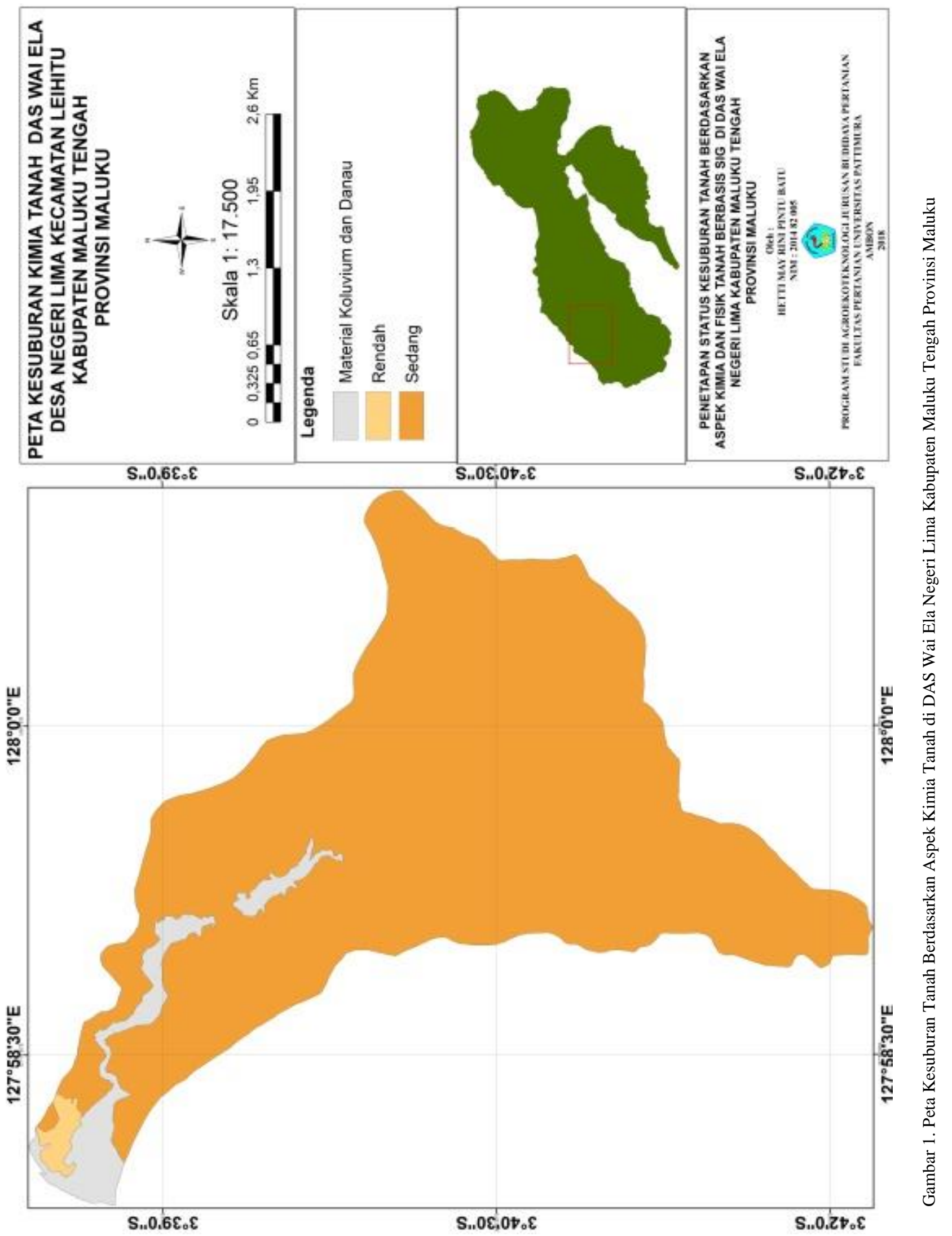




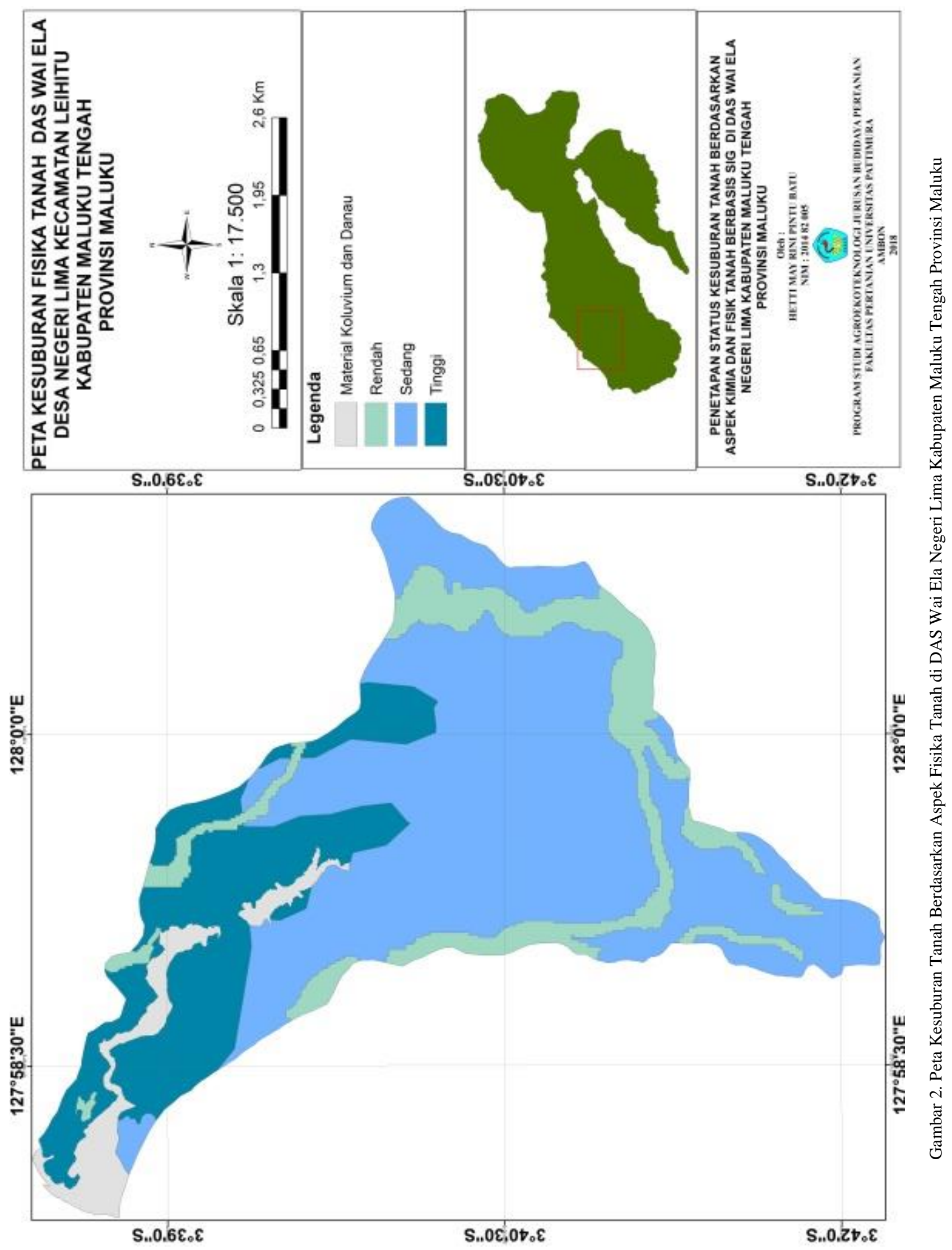




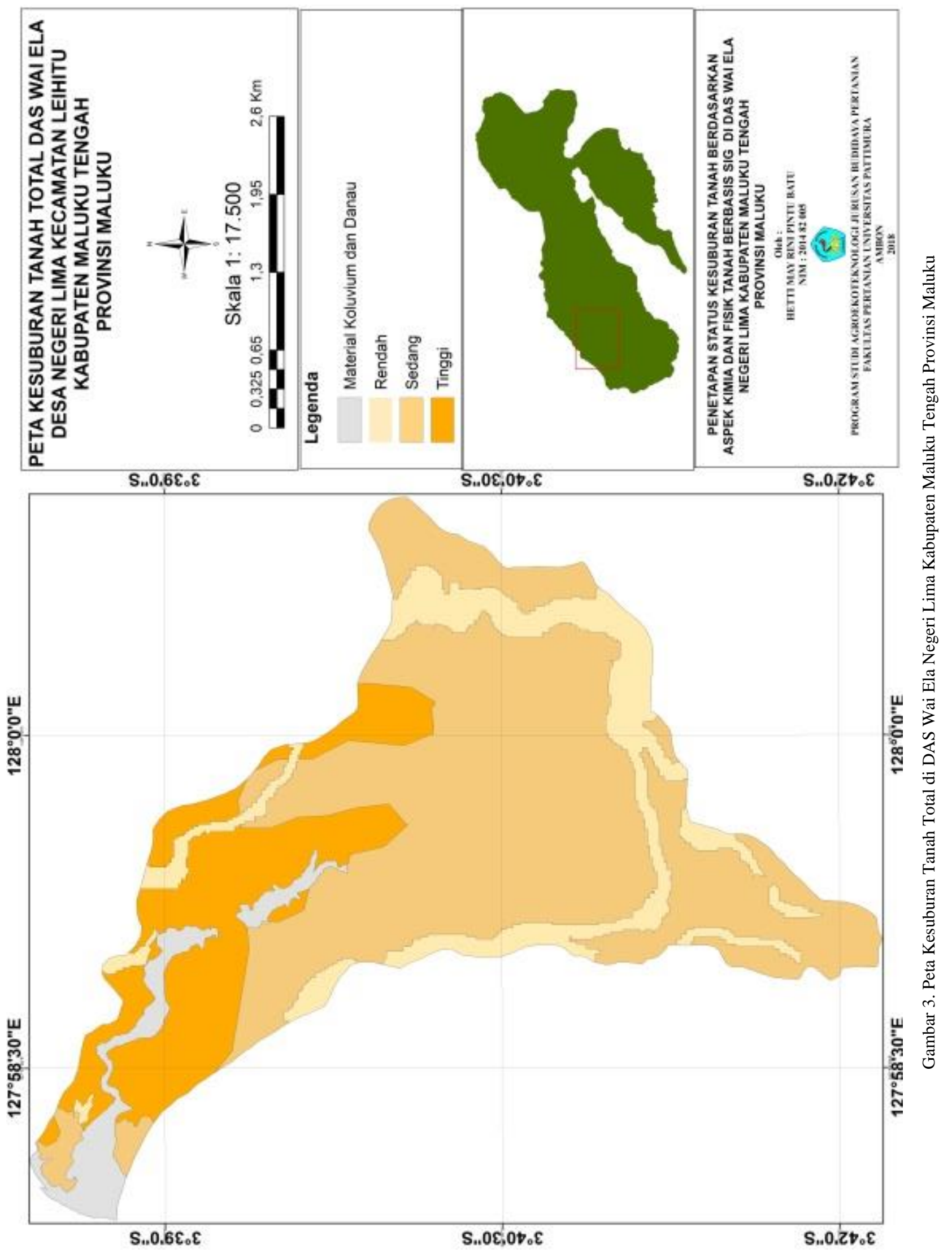


Tabel 9. Arahan perbaikan kesuburan tanah

\begin{tabular}{|c|c|c|c|c|c|c|}
\hline \multirow{2}{*}{ KTT } & \multirow{2}{*}{ Jenis Tanah } & \multicolumn{2}{|c|}{ Status kesub. } & \multicolumn{2}{|c|}{ Faktor Pembatas } & \multirow{2}{*}{ Arahan } \\
\hline & & Kimia & Fisika & Kimia & Fisik & \\
\hline \multirow[t]{2}{*}{ Rendah (R) } & Gleisol Eutrik & $S$ & $\mathrm{R}$ & $\mathrm{N}(\mathrm{R})$ & $\begin{array}{l}\text { Tekstur (R) } \\
\text { Permeabilitas (R) }\end{array}$ & $\begin{array}{l}\text { Pemberian pupuk urea, kompos } \\
\text { dan penanaman tanaman legum } \\
\text { (kacang-kacangan) }\end{array}$ \\
\hline & Litosol & $\mathrm{S}$ & $\mathrm{R}$ & $\begin{array}{l}\mathrm{P}_{2} \mathrm{O}_{5}(\mathrm{R}) \\
\mathrm{N}(\mathrm{SR})\end{array}$ & $\begin{array}{l}\text { Kedalaman (R) } \\
\text { Permeabilitas (R) }\end{array}$ & $\begin{array}{l}\text { Pemberian pupuk urea dan } \mathrm{SP}_{36} \\
\text { dan pemberian kompos, dengan } \\
\text { catatan tanaman yang mau } \\
\text { ditanam berakar dangkal (tanaman } \\
\text { setahun) }\end{array}$ \\
\hline \multirow[t]{3}{*}{ Sedang (S) } & Aluvial Eutrik & $\mathrm{R}$ & $\mathrm{T}$ & $\begin{array}{l}\mathrm{P}_{2} \mathrm{O}_{5}(\mathrm{R}) \\
\mathrm{N}(\mathrm{SR})\end{array}$ & Permeabilitas (S) & $\begin{array}{l}\text { Pemberian pupuk urea dan } \mathrm{SP}_{36} \text {, } \\
\text { kompos dan penanaman tanaman } \\
\text { legum (kacang-kacangan) }\end{array}$ \\
\hline & $\begin{array}{l}\text { Kambisol } \\
\text { Distrik }\end{array}$ & S & $S$ & $\mathrm{~N}(\mathrm{R})$ & $\begin{array}{l}\text { Kedalaman (S) } \\
\text { Permeabilitas (R) }\end{array}$ & $\begin{array}{l}\text { Pemberian pupuk urea, kompos, } \\
\text { penanaman tanaman legum } \\
\text { (kacang-kacangan) dan } \\
\text { pengolahan tanah yang intensif }\end{array}$ \\
\hline & $\begin{array}{l}\text { Molisol } \\
\text { Haplik }\end{array}$ & S & S & $\mathrm{N}(\mathrm{SR})$ & permeabilitas (R) & $\begin{array}{l}\text { Pemberian pupuk urea, kompos } \\
\text { dan penanaman tanaman legum } \\
\text { (kacang-kacangan) }\end{array}$ \\
\hline Tinggi (T) & $\begin{array}{l}\text { Kambisol } \\
\text { Eutrik }\end{array}$ & $\mathrm{S}$ & $\bar{T}$ & $\begin{array}{l}\text { C-organik (SR) } \\
\mathrm{N}(\mathrm{R})\end{array}$ & - & $\begin{array}{l}\text { Pemberian pupuk urea, kompos } \\
\text { dan penanaman tanaman legum } \\
\text { (kacang-kacangan) }\end{array}$ \\
\hline
\end{tabular}

\section{KESIMPULAN}

Sifat kimia tanah di DAS Wai Ela Negeri Lima Kecamatan Leihitu Kabupaten Maluku Tengah Provinsi Maluku menunjukkan Kapasitas Tukar Kation (KTK) tinggi sampai sangat tinggi, Kejenuhan Basa (KB) sangat tinggi, C-Organik mulai dari sangat rendah- sangat tinggi, $\mathrm{P}_{2} \mathrm{O}_{5}$ tersedia rendah sampai sangat tinggi dan Nitrogen (N_total) sangat rendah sampai rendah. Sifat fisik tanah antara lain kedalaman tanah berkisar antara rendah dan tinggi, tekstur tanah antara lempung, liat berdebu, lempung liat berpasir dan lempung berpasir, serta laju permeabilitas berkisar antara rendah sampai tinggi.

Status kesuburan tanah di DAS Wai Ela Negeri Lima Kecamatan Leihitu Kabupaten Maluku Tengah Provinsi Maluku pada setiap jenis tanah adalah rendah sampai dengan tinggi, yakni jenis tanah Gleisol Eutrik dan Litosol berada pada status kesuburan yang rendah, jenis tanah Aluvial Eutrik, Kambisol Distrik dan Molisol Haplik berada pada status kesuburan sedang dan jenis tanah Kambisol Eutrik berada pada status kesuburan yang tinggi.

Usaha perbaikan kesuburan tanah yang dapat dilakukan di DAS Wai Ela Negeri Lima Kecamatan Leihitu Kabupaten Maluku Tengah Provinsi Maluku antara lain manajemen pemupukan berimbang sesuai kebutuhan tanaman, penambahan bahan organik (pupuk kandang, pupuk hijau atau penanaman legume) pada tahapan pengolahan tanah, manajemen $\mathrm{pH}$ tanah yang sesuai untuk ketersediaan unsur dengan pengapuran (menaikkan $\mathrm{pH}$ ), dan pengaturan air irigasi yang tepat.

\section{DAFTAR PUSTAKA}

Arsyad, S. 1989. Konservasi Tanah dan Air. IPB Press. Bogor.

Delvian, 2010. Konservasi Daerah Aliran Sungai. Dalam Prosiding Seminar dan Lokakarya Nasional, Medan, 12-13 Februari 2010. Hal 103-112.

Jauhari, M.A. 2009. Agihan Kesuburan Tanah Pada Lahan Padi Sawah Di Kecamatan Jogorogo Kabupaten Ngawi Provinsi Jawa Timur. Skripsi. Fakultas Geografi. Universitas Muhammadiyah Surakarta.

Jordan, D. and R.J. Kremer. 1994. Potential Use of Soil Microbial Activity as an Indicator of Soil Quality. In: Soil Biota, Management in Sustainable Farming System. Editors: Pankhurst, C.E., B.M. Doube, V.V.S.R. Gupta, P.R. Grace. CSIRO. Australia. pp.245-249

[PPT] Pusat Penelitian Tanah. 1983. Analisis Kimia Tanah, Tanaman, Air dan Pupuk. Departemen Pertanian, Bogor.

Sitorus, S. 1985. Evaluasi Sumber Daya Lahan. Penerbit Tarsito Bandung.

Talakua, S.M. 2016. Degradasi Lahan (Metode Analisis dan Aplikasinya Dalam Penggunaan Lahan). Penerbit Plantaxia. Yogyakarta.

Talakua, S.M. and E. Kaya. 2019. Influence of organic fertilizer sago compost on ultisol soil physical properties of Telaga Kodok Sub Village in Hitu Village of Central Maluku District and the Corn (Zea mays L.) crops production. Science Nature 2: 42-56. 
Talakua, S.M. and R.M. Osok. 2019. Development of a Land Degradation Assessment Model Based on Field Indicators Assessment and Prediction Method in Wai Sari Sub Watershed Kairatu District, Western Seram Regency Maluku Province - Indonesia. Science Nature 2: 71-84.
Waluyaningsih, S.R. 2008. Studi Analisis Kualitas Tanah pada Beberapa Penggunaan Lahan dan Hubungannya Dengan Tingkat Erosi di Sub DAS Keduang Kecamatan Jatisrono Wonogiri. Tesis. Program Studi Ilmu Lingkungan, Program Pascasarjana Universitas Sebelas Maret, Surakarta. 